\title{
Intraspecific and interspecific variation in the sequence and abundance of highly repeated DNA among mosquitoes of the Aedes albopictus subgroup
}

\author{
Denson Kelly McLain* \\ Karamjit S. Rai and \\ Malcolm J. Fraser
}

Department of Biological Sciences, University of Notre Dame, Notre Dame, IN 46556, U.S.A.

Interspecific variation in abundance of highly repeated DNA sequences has been examined in three species of the Aedes scutellaris and three species of the $A$. albopictus subgroup of the A. scutellaris group. Sequences from a population of $A$. albopictus were hybridised with whole genomic content from other species and strains. Copy number estimates were determined by dot-blot hybridisation. Variation in sequence abundance between strains of $A$. albopictus was as great as between it and the other six species. Two clusters were formed by principal components analysis, each of which contains populations of $\boldsymbol{A}$. albopictus. Copy numbers of highly repeated sequences do not correlate with genome size. The results indicate extensive sequence divergence and rapid evolution. These findings are discussed in relation to the importance of concerted evolution and natural selection in the evolution of the species group.

\section{INTRODUCTION}

Most eukryote genomes contain hundreds or thousands of families of highly repeated DNA sequences (John and Miklos, 1979; Brutlag, 1980; Bouchard, 1982) varying in sequence length from ten to several thousand base pairs (Maresca et al., 1984; Skowronski et al., 1984) and constituting up to 80 per cent of the genome (MacGregor, 1982). Variation in both sequence (Pages and Roizes, 1984; Maresca et al., 1984) and abundance (Dover, 1981; Singer, 1982; Bouchard, 1982) of highly repeated sequences occurs between closely related species. Some sibling species of Drosophila differ by an order of magnitude in the abundance of dispersed repetitive DNA (Dowsett and Young, 1982; Strachan et al., 1982). Changes in abundance may have important evolutionary consequences through indirect effects on developmental time (Cavalier-Smith, 1982) and rates or localisation of recombination (John and King, 1985).

The present study examines interspecific variation in the abundance of highly repeated DNA sequences in three species of the Aedes scutellaris subgroup and three species of the $A$. albopictus subgroup of the $A$. scutellaris group. The $A$. scutellaris group consists of 34 species in the scutellaris

\footnotetext{
* Present address: Department of Biology, Emory University, Atlanta, Georgia 30322, U.S.A.
}

subgroup, confined primarily to Polynesia and Melanesia, and 11 African, Asian, and Pacific species in the albopictus subgroup (Rai et al., 1982). Also, intraspecific variation in sequence abundance, which has received little study (Maresca et al., 1984), is examined in 15 strains of $\boldsymbol{A}$. albopictus derived from geographic locations extending from Madagascar through India, southeastern Asia, and the Pacific. Within the $A$. scutellaris group genome size varies from less than $0.5 \mathrm{pg}$ to over $1.3 \mathrm{pg}$ per haploid genome (Rao and Rai, 1986), with moderately-highly repeated sequences accounting for the variation (Black and Rai, in preparation).

Species of the two subgroups diverged approximately 10 million years ago as judged from allozyme variation and geologic history (Pashley and Rai, 1983). In the $A$. scutellaris subgroup, $A$. malayensis appears to have diverged from $A$. hebrideus 2-3 million years ago, and from $A$. pseudoscutellaris 7-10 million year, ago (Pashley et al., 1985). A. hebrideus and A. pseudoscutellaris appear to have diverged about 5 million years ago (Pashley et al., 1985). Phylogenetic relationships within the $A$. albopictus subgroup have yet to be elucidated, although $A$. pseudalbopictus and $A$. seatoi are probably more closely related to each other than to A. albopictus while A. flavopictus is probably relatively distantly related to the other three species (Rai et al., 1982). Species within the 
A. albopictus subgroup reflect a recent radiation relative to the $A$. scutellaris subgroup (McLain and Rai, 1986; McLain et al., 1985).

The objectives of the present study are to determine if changes in sequence and abundance: (a) evolve rapidly, (b) promote postmating reproductive isolation, and (c) are responses to selection pressure. The experimental approach was to hybridise highly repetitive sequences isolated from a single population of $A$. albopictus (Oahu, Hawaii, U.S.A.) to whole genomic DNA from other species and strains. Copy number estimates of the sequences were determined through quantitative dot-blot hybridisation. Sequence variation was revealed by differential hybridisation at low versus high stringency.

\section{METHODS}

\section{DNA isolation and cloning}

DNA was isolated from larvae or pupae by the procedure of Fleming et al. (1983), as modified from Fuchs and Green (1979). Following ethanol precipitation DNA was resuspended in sterile water and stored at $4^{\circ} \mathrm{C}$.

DNA from $A$. albopictus (Oahu strain) was digested for 2 hours with restriction enzyme Eco RI (Bethesda Research Laboratories [BRL], Gaithersburg, MD, U.S.A.; used 10 units/ $\mu$ g DNA) and ligated to restricted plasmid pUC 12 which contains an Eco RI site within a lac Z gene (Vieira and Messing, 1982) permitting selection of recombinants on LB media coated with 2 per cent bluo-gal (from BRL) in dimethyl formamide. Ligation and subsequent transformation into $E$. coli strain JM83 was performed as described in Maniatis et al. (1982). Transformants were selected on media containing $50 \mu \mathrm{g}$ ampicillin $/ \mathrm{ml}$.

\section{Detection of repetitive sequences}

Clones of length $1000-7000$ base pairs were nick translated (BRL kit \# 81065B) to incorporate labelled deoxycytidine and then hybridised to Hind III digested (10 units/ $\mu$ g DNA for 12 hours; enzyme from BRL), whole genomic DNA immobilised on nitrocellulose paper (Southern, 1975). Transfer of DNA from a 1 per cent agarose gel to nitrocellulose was as described in Smith and Summers (1980). Hybridisation was performed under stringent conditions (50 per cent formamide, $2 \times$ SSC) with washing at $65^{\circ} \mathrm{C}$ (Smith and Summers, 1980). Autoradiography utilised Kodak XRP-1 film intensified with a Dupont Cronex Lightening Plus screen at $-80^{\circ} \mathrm{C}$. Repeated sequences yielded a smear of hybridisation (fig. 1) while low copy sequences produced a single band or no detectable hybridization. Eight clones ranging in size from $1000-7000$ base pairs containing highly repeated sequences were thus identified. None of these clones cross-hybridizes at low stringency (1.0 per cent formamide, $5 \times \mathrm{SSC}$, washing at $42^{\circ} \mathrm{C}$ ). Restriction mapping of clones has revealed no tandem repetition of sequences (Ferrari and Rai, in preparation), indicating, perhaps, that the repetitive sequences in the clones are dispersed.

\section{Variation in abundance and dot-blot hybridization}

Fifteen $\mu \mathrm{g}$ of unrestricted, RNase A-treated, genomic DNA in $2 \mathrm{M}$ sodium acetate was dotted (Kafatos et al., 1979) onto untreated nitrocellulose paper using a dot-blot minifold (Schleicher and Schuell, Keene, NH, U.S.A.). For each nick-translated probe, DNA from all 21 strains and species was simultaneously hybridised on the same sheet of nitrocellulose. Differences in the abundance of a repeated sequence were revealed by differences in the intensity of autoradiographic dots (fig. 1), and quantified through densitometry tracings which yield a series of peaks each corresponding in size to the intensity of a particular dot. There is a linear relationship between the intensity of a dot and the amount of mosquito DNA bound on nitrocellulose (McLain et al., 1986; see also Small et al., 1982). Dot hybridisation has proven effective in detecting differences in sequence abundance in numerous other studies (e.g., Collins and Groudine, 1982; Hamada and Kakunaga, 1982; Law et al., 1982).

The copy number estimates for sequences in the genome of $\boldsymbol{A}$. albopictus (Oahu strain) were calculated via the procedure of Brandsma and Miller (1980; see also Hamada and Kakunaga, $1982)$ by dotting $300 \mathrm{ng}$ of plasmid DNA $\left(=3 \times 10^{12}\right.$ copies) alongside $15 \mu \mathrm{g}$ of mosquito genomic DNA $\left(=1.5 \times 10^{7}\right.$ copies of the genome; note, $1 \mathrm{pg}$ of $\mathrm{DNA}=10^{9}$ base pairs [Strauss, 1971]). Dot intensities were then compared from hybridisations with each cloned sequence (plasmid vector + repeating sequence). Copy numbers could be estimated for other species and strains by direct comparison with Oahu of dot intensity and genome size (Rao and Rai, 1986).

Isolation of DNA for dot blotting, dot blot hybridisations, and copy number estimates were determined twice. The copy number estimates were very consistent (relative to variation between 

A. SOUTHERN BLOT
B. DOT BLOT and DENSITOMETRY TRACING

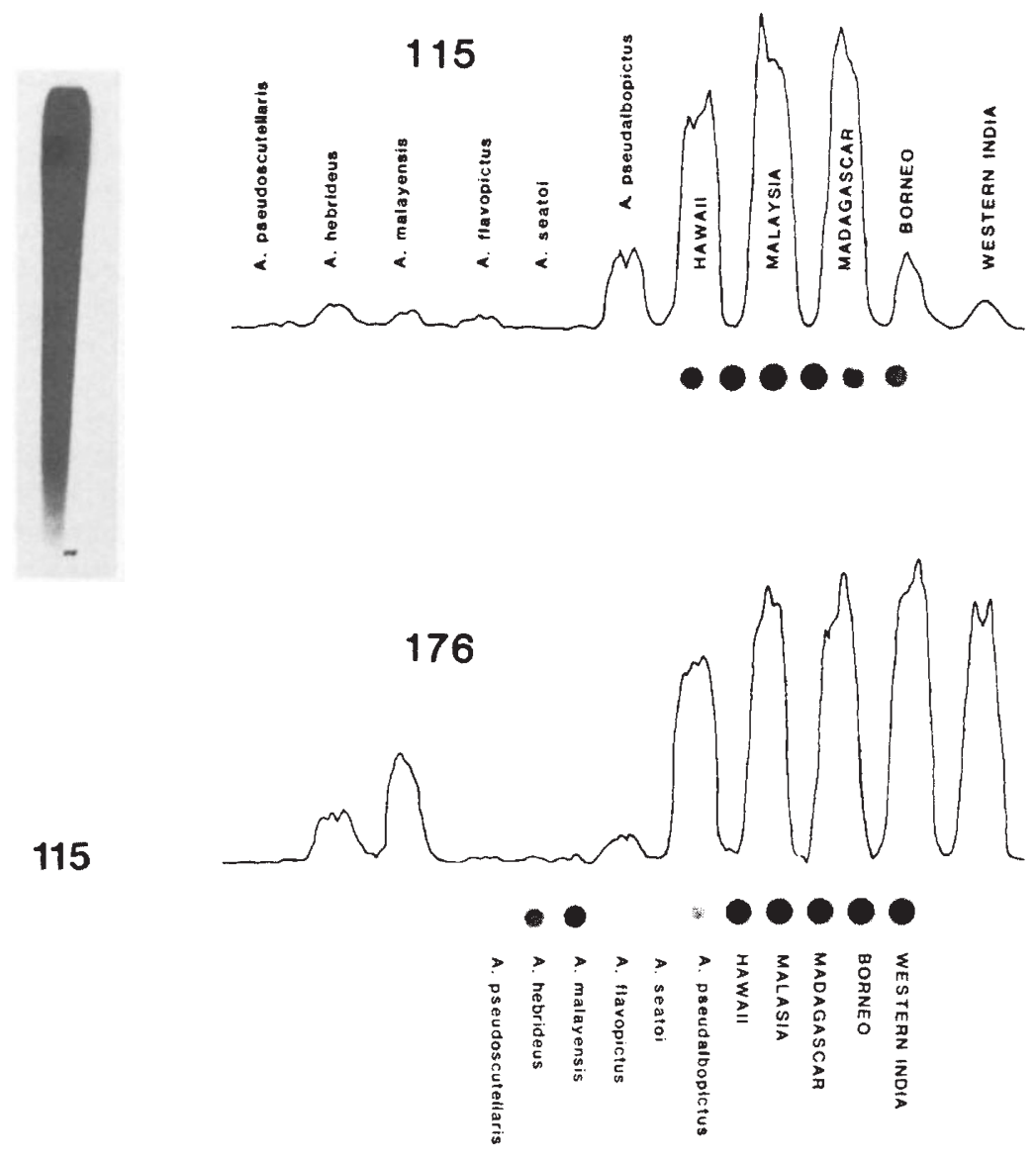

Figure 1 A. Autoradiograph of total genomic DNA digested with Hind III, Southern blotted to nitrocellulose, and then hybridised with a clone (H-115) containing highly repeated sequences. B. Dot blots and densitometry tracings of those dots representing the variation in abundance in seven species (including five strains of $A$. albopictus) of two clones of highly repeated sequences (H-115 and $\mathrm{H}-176$ ).

populations), varying by $10-20$ per cent for clones with copy numbers of at least 10,000 and by $20-30$ per cent for clones with copy numbers of less than 10,000 . Therefore, the data are presented as averages.

Some error in estimates of sequence abundance may occur if sequence variation affects the efficiency of hybridisation for those species hybridising to Oahu probes at high stringency. Also, it is not known how much sequence variation exists in these species. Since highly repeated sequences evolve rapidly through single base substitution (Pages and Roizes, 1984), a given family may be represented by different sequence variants (e.g., Dover, 1982; Dover et al., 1982). Thus, sequence variation could partially obscure differences in abundance. This variation is potentially important since the $A$. albopictus and $A$. scutellaris subgroups diverged approximately 10 million years ago (Pashley et al., 1985; Pashley and Rai, 1983). However, it is unlikely that there is much sequence variation within a family within a given population since the rate of homogenisation of a variant is high relative to the mutation rate (Strachan et al., 1985).

To test for the applicability of dot-blotting to estimate copy number, species and strains hybridising to Oahu probes at high stringency were also hybridised at low stringency. The abundance of sequences relative to the Oahu genome was compared as a function of stringency. With the exception of $A$. albopictus strains from central 
India, Thailand, and the Solomon Islands, the abundance of sequences in all the other strains did not vary by more than $20-30$ per cent at high and low stringency. This is within the error for different replicates at high stringency. Since copy number estimates did not vary as a function of stringency, we conclude that sequence variation does not significantly affect estimates of copy number.

\section{Species utilised.}

DNA was cloned from $A$. albopictus from Oahu for several reasons. First, the population is at the eastern edge of the geographic range of the species. Therefore, other strains used vary greatly in geographic proximity. Second, several other strains are available from Hawaii permitting the analysis of differences between populations that are, presumably, closely related. Third, the Oahu strain has a relatively large genome size (Rao and Rai, 1986), suggesting an abundance of repeated sequences.

Table 1 lists the date of colonisation of all strains and species. Fig. 2 depicits the species' geographic distributions.

Table 1 Dates of colonisation and sources of species and strains

\begin{tabular}{|c|c|c|}
\hline $\begin{array}{l}\text { Species } \\
\text { (albopictus subgroup) }\end{array}$ & Date & Source \\
\hline \multirow[t]{15}{*}{ Aedes albopictus } & 1966 & Saigon, Viet Nam \\
\hline & 1968 & Surot Thani, Thailand \\
\hline & 1971 & Oahu, Hawaii \\
\hline & 1973 & $\begin{array}{l}\text { Kuala Lumpur, } \\
\text { Malaysia }\end{array}$ \\
\hline & 1974 & $\begin{array}{l}\text { Tananareve, } \\
\text { Madagascar }\end{array}$ \\
\hline & 1977 & Taipei, Taiwan \\
\hline & 1977 & Tokyo, Japan \\
\hline & 1978 & $\begin{array}{l}\text { Kalimantan, Indonesia } \\
\text { (Borneo) }\end{array}$ \\
\hline & 1978 & Hong Kong \\
\hline & 1979 & Korea \\
\hline & 1981 & Kahoolawe, Hawaii \\
\hline & 1982 & $\begin{array}{l}\text { Guadal Canal, Solomon } \\
\text { Islands }\end{array}$ \\
\hline & 1984 & $\begin{array}{l}\text { Pune, India (Central } \\
\text { India) }\end{array}$ \\
\hline & 1984 & $\begin{array}{l}\text { Coonor, India (West. } \\
\text { India) }\end{array}$ \\
\hline & 1984 & Kauai, Hawaii \\
\hline A. pseudalbopictus & 1981 & Chiayi Hsien, Taiwan \\
\hline A. seatoi & 1972 & Bangkok, Thailand \\
\hline $\begin{array}{l}\text { A. flavopictus } \\
\text { (scutellaris subgroup) }\end{array}$ & 1981 & Nagasaki, Japan \\
\hline A. pseudoscutellaris & 1979 & Suva, Fiji \\
\hline A. hebrideus & 1982 & South Pentecost \\
\hline A. malayensis & 1968 & Prachaup, Thailand \\
\hline
\end{tabular}

\section{RESULTS}

Estimated copy numbers for the eight cloned highly repeated sequences within the genome of the Oahu strain of A. albopictus range from 3900 (sequence $\mathrm{H}-176$ ) to 470,000 (sequence $\mathrm{H}-85$ ) (table 2). Between populations of $A$. albopictus copy numbers varied significantly for any given sequence (table 2). For instance, sequence $\mathrm{H}-85$ was not detected in the population from Japan (high stringency hybridisation) but contains an estimated 2.6 million copies in the genome of the population from Thailand.

The abundance of the eight highly repeated sequences in $A$. albopictus (Oahu strain) was significantly $(P<0.05)$, positively correlated with the abundance in three other albopictus subgroup species (A. pseudalbopictus, $r=0.912 ; A$. seatoi, $r=0.997$; A. flavopictus, $r=0.995$ if sequence $\mathrm{H}-85$ is omitted, otherwise, $r=0.432, P>0.05$ ). Correlations between abundance in A. albopictus (Oahu) and the three scutellaris subgroup species are significant $(P<0.05)$ only when sequence $\mathrm{H}-85$ is omitted (A. malayensis, $r=0.417$ or $r=0.995$ omitting $\mathrm{H}-85 ; A$. hebrideus, $r=0.418$ or $r=0.996$ omitting $\mathrm{H}-85 ; A$. pseudoscutellaris, $r=0.413$ or $r=0.928$ omitting $\mathrm{H}-85$ ).

Three of the repeated sequences (in clones $\mathrm{H}-19, \mathrm{H}-85$, and H-115) did not hybridise to some strains of $A$. albopictus or other species under stringent conditions (table 2). However, in every instance hybridisation occurred at low stringency.

The variation in sequence abundance between strains of $A$. albopictus was as great as that between $A$. albopictus and the six other species. In a principal components analysis (fig. 3), two clusters were formed from the plot of the first two principal components, accounting for 84.3 per cent of the variation in the data. Each cluster contains populations of $A$. albopictus and other species from both subgroups. Only a few populations of $\boldsymbol{A}$. albopictus are not present in one or the other cluster.

The seven strains and species in the lower cluster contain relatively low copy numbers of the repeated sequences. The mean of the sum of the copy number for all eight sequences for these seven strains and species is $94,000(S D=56,000)$. The mean of the eight strains and species of the upper cluster $($ mean $=545,000, S D=144,000)$ is significantly greater $(P<0.05 ; t=8.16)$ than the mean for the lower cluster. The lower cluster consists entirely of island populations. Six of the eight populations in the upper cluster are from Malaysia or mainland and large islands immediately adjacent. 


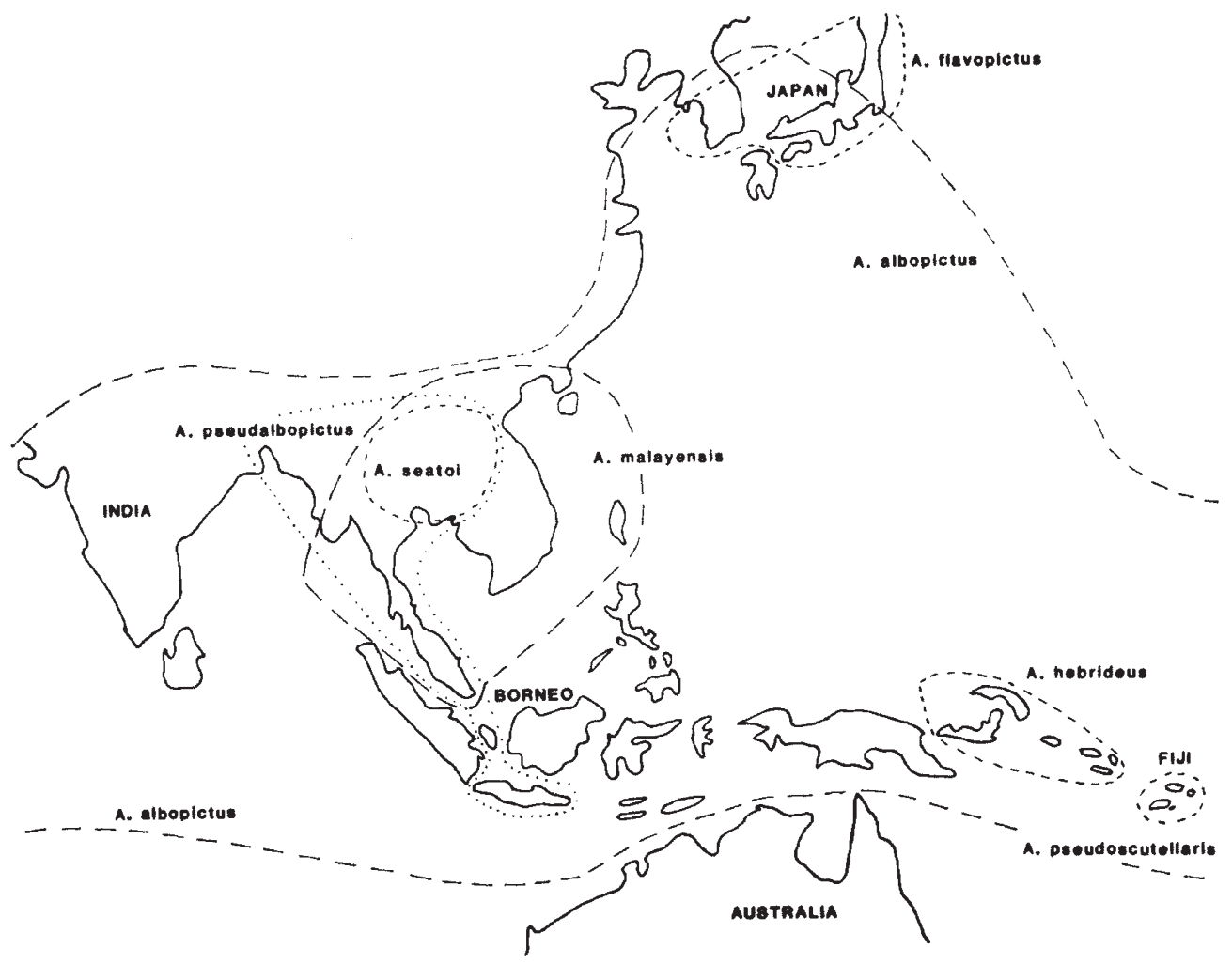

Figure 2 Geographic distribution in the Pacific and south-eastern Asia of the seven A. scutellaris group species employed in the present study.

Table 2 Abundance of eight highly repeated sequences in fifteen strains of $A$. albopictus and six other species in the $A$. scutellaris group

\begin{tabular}{|c|c|c|c|c|c|c|c|c|}
\hline \multirow[b]{2}{*}{ Species/strain } & \multirow[b]{2}{*}{ H-19 } & \multirow[b]{2}{*}{$\mathrm{H}-41$} & \multicolumn{3}{|c|}{ Sequence } & \multirow[b]{2}{*}{$\mathrm{H}-85$} & \multirow[b]{2}{*}{$\mathrm{H}-115$} & \multirow[b]{2}{*}{$\mathrm{H}-176$} \\
\hline & & & H-61 & $\mathrm{H}-75$ & $\mathrm{H}-76$ & & & \\
\hline \multicolumn{9}{|l|}{ A. albopictus } \\
\hline Oahu & 11,000 & 310,000 & 19,000 & 19,000 & 140,000 & 470,000 & 5,800 & 3,900 \\
\hline Kahoolawe & 0 & 2,600 & 1,800 & 1,100 & 4,000 & 72,000 & 0 & 2,200 \\
\hline Kauai & 0 & 5,900 & 2,200 & 1,100 & 11,000 & 130,000 & 3,000 & 2,700 \\
\hline Solomon Islands & 4,900 & 160,000 & 15,000 & 17,000 & 140,000 & 160,000 & 3,200 & 14,000 \\
\hline Japan & 590 & 4,200 & 1,200 & 2,400 & 3,900 & 0 & 8,700 & 16,000 \\
\hline Hong Kong & 920 & 2,000 & 920 & 100 & 6,400 & 110,000 & 21,000 & 15,000 \\
\hline Taiwan & 240 & 510 & 1,800 & 190 & 17,000 & 69,000 & 9,900 & 18,000 \\
\hline Korea & 1,300 & 160,000 & 4,600 & 11,000 & 160,000 & 150,000 & 16,000 & 17,000 \\
\hline Viet Nam & 1,800 & 61,000 & 6,200 & 6,400 & 59,000 & 810,000 & 32,000 & 29,000 \\
\hline Thailand & 5,500 & 150,000 & 15,000 & 13,000 & 100,000 & 260,000 & 39,000 & 81,000 \\
\hline Central India & 4,300 & 280,000 & 9,600 & 3,500 & 90,000 & 55,000 & 480 & 4,400 \\
\hline Western India & 5,600 & 18,000 & 3,600 & 4,500 & 17,000 & 93,000 & 7,500 & 27,000 \\
\hline Malaysia & 2,800 & 320,000 & 18,000 & 8,100 & 120,000 & 250,000 & 3,400 & 6,000 \\
\hline Borneo & 6,200 & 200,000 & 7,400 & 5,800 & 100,000 & 290,000 & 1,100 & 9,100 \\
\hline Madagascar & 7,100 & 280,000 & 10,000 & 8,200 & 110,000 & 270,000 & 6,800 & 8,800 \\
\hline A. pseudalbopictus & 750 & 280,000 & 16,000 & 11,000 & 110,000 & 210,000 & 2,000 & 560 \\
\hline A. seatoi & 3,500 & 150,000 & 11,000 & 7,300 & 86,000 & 240,000 & 0 & 0 \\
\hline A. flavopictus & 0 & 58,000 & 1,400 & 100 & 20,000 & 0 & 180 & 0 \\
\hline A. malayensis & 2,500 & 250,000 & 17,000 & 12,000 & 87,000 & 0 & 120 & 2,700 \\
\hline A. hebrideus & 2,200 & 190,000 & 12,000 & 8,900 & 68,000 & 0 & 430 & 410 \\
\hline A. pseudoscutellaris & 260 & 19,000 & 1,700 & 400 & 1,400 & 0 & 0 & 0 \\
\hline
\end{tabular}




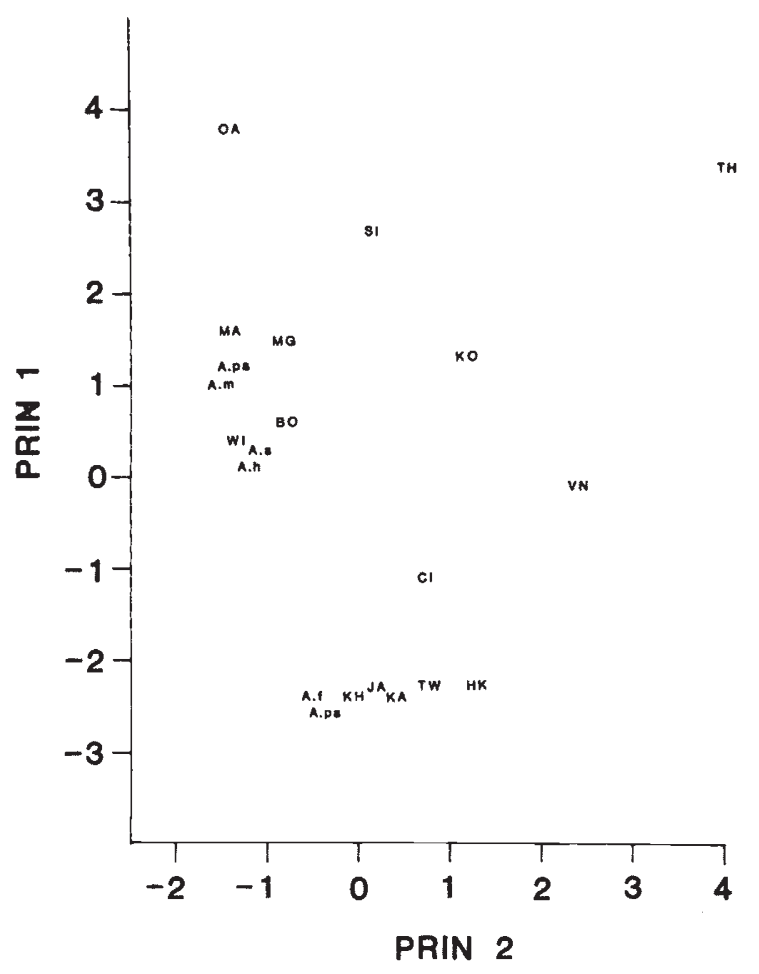

Figure 3 Clustering of the fifteen strains of $\boldsymbol{A}$. albopictus and six other species produced from the plot of the first two principal components (explaining 84.3 per cent of the variation) resulting from a PCA on the abundances of eight highly repeated sequences. Lower cluster: A. $\mathrm{f}=$ A. flavopictus; A. ps =A. pseudoscutellaris; and A. albopictus strains, $\mathrm{KH}=$ Kahoolawe (Hawaii), JA= Japan, $\mathrm{KA}=\mathrm{Kauai}$ (Hawaii), $\mathrm{TW}=$ Taiwan, and $\mathrm{HK}=$ Hong Kong. Upper cluster: $\mathrm{A} . \mathrm{hs}=\boldsymbol{A}$. hebrideus; $\mathrm{A} . \mathrm{s}=\boldsymbol{A}$. seatoi; $\mathrm{A} \cdot \mathrm{m}=\boldsymbol{A}$. malayensis, A. pa $=A$. pseudalbopictus; and A. albopictus strains, $\quad W I=$ western India, $\quad B O=$ Borneo, $\quad M G=$ Madagascar, and MA $=$ Malaysia. Other non-clustered $A$. albopictus strains, $\mathrm{VT}=$ Viet $\mathrm{Nam}, \mathrm{CI}=$ central India, $\mathrm{TH}=$ Thailand, $\mathrm{KO}=$ Korea, $\mathrm{SI}=$ Solomon Islands, and $\mathrm{OA}=$ Oahu (Hawaii).

None of the highly repeated sequences have copy numbers which correlate significantly with genome size (data from Rao and Rai, 1986) in regression analyses employing: (a) fifteen strains of $A$. albopictus, (b) all 21 strains and species, or (c) the three scutellaris and three albopictus subgroup species (excluding $A$. albopictus) (table 3).

\section{DISCUSSION}

The highly repetitive component of the genome evolves very rapidly. This is supported by: (a) extensive variation in abundance between sibling species in both the $A$. scutellaris and $A$. albopictus
Table 3 Correlation (Pearson's linear) between the abundance of a highly repeated sequence and genome size. For each sequence the correlation is determined for strains of $A$. albopictus $(n=15)$, all strains of $A$. albopictus plus the six other scutellaris group species $(n=21)$, and the scutellaris group species excluding $A$. albopictus $(n=6)$

\begin{tabular}{llll}
\hline & $\begin{array}{l}\text { A. albopictus } \\
\text { Strains }\end{array}$ & $\begin{array}{l}\text { Strains } \\
\text { and other } \\
\text { species }\end{array}$ & $\begin{array}{l}\text { Species } \\
\text { excluding } \\
\text { A. albopictus }\end{array}$ \\
\hline H-19 & 0.024 & 0.174 & -0.178 \\
H-43 & -0.347 & -0.169 & 0.311 \\
H-61 & -0.491 & -0.272 & 0.276 \\
H-75 & -0.039 & 0.017 & 0.257 \\
H-76 & 0.308 & 0.286 & 0.466 \\
H-85 & -0.234 & -0.002 & 0.348 \\
H-115 & -0.370 & 0.048 & 0.644 \\
H-176 & -0.253 & -0.163 & -0.013 \\
\hline
\end{tabular}

subgroups, and (b) variation within the single species, A. albopictus, which is as great as that between species. Evolution within the highly repetitive component of the genome has occurred through sequence amplification or diminution and through sequence variation. Extensive sequence divergence is revealed by hybridisation at low stringency following failure to hybridise at high stringency (which requires more precise base pairing). Other studies used this approach to document sequence divergence between sibling species (Strachan et al., 1982; Jeffreys, 1982).

The occurrence of sequence variation between sibling species or between populations of a single species indicates that some cytological processes such as unequal crossing over or gene (sequence) conversion are homogenising populations as different mutants arise (Dover, 1982; Nagylaki and Petes, 1982; Nagylaki, 1984). Such concerted evolution (Dover, 1982; Dover et al., 1982; Dover, 1986) can result from a bias toward a sequence variant in gene (sequence) conversion, promoting the rapid fixation within a population of the preferred variant (Ohta and Dover, 1983 and 1984; Ohta, 1985). Rapid concerted evolution is indicated in the present study by tremendous intraspecific variation in the abundance of different sequence variants. Variation within a population is probably of limited extent since the process of replacing one sequence variant with another (molecular drive) by gene conversion, unequal crossing-over, or through stochastic gain-and-loss conversion is a slow process relative to the rate of random distribution of chromosomes which accompanies sexual reproduction (Ohta and Dover, 1984). An interesting consequence of this is that selection differentials between individuals will be too small for 
natural selection to oppose the spread of a variant even if it reduces mean population fitness.

The PCA clustering may indicate selection pressure, perhaps imposed by habitat, for the maintenance of particular abundance profiles of the highly repeated sequences. Thus, there is clustering of geographically contiguous but taxonomically diverse species. For instance, six of eight species and populations in one cluster are from Malaysia or adjacent areas. These include two strains of $\boldsymbol{A}$. albopictus (from Borneo and Malaysia), two other albopictus subgroup species, A. pseudalbopictus and A. seatoi (from Malaysia and Thailand, respectively), and two scutellaris subgroup species, $A$. malayensis and $A$. hebrideus (from Malaysia and Melanesia, respectively). The abundance profiles of species in this cluster appear stable since species in the two subgroups have probably been isolated for 10-15 million years (Pashley et al., 1985). It is unlikely that there has been horizontal transfer (introgression) of sequences since there is complete post-mating and complete or significant pre-mating isolation between species (McLain et al., 1985; McLain and Rai, 1986). Similarly, for six species of the A. scutellaris subgroup the abundance profiles of nine highly repeated sequences (cloned from $A$. malayensis) are very similar among species pairs occurring on small islands in Polynesia, large islands in Melanesia, or continents (Asia and Australia). Again, these similarities were not associated with well established phylogenetic relationships among the species (McLain et al., 1986).

These associations suggest the action of natural selection. However, the interaction between selection and forces responsible for changes in sequence or copy number of repetitive DNA is complex (Dover, 1986). This complexity arises in part because natural selection is blind to the small differentials between individuals (Dover and Ohta, 1984), as previously outlined. Therefore, the genome need not reflect adaptation to the environment. Instead, it may reflect "adoptation" (Dover, 1986). "Adoptation" occurs if internally driven changes in the genome are not counterpoised by molecular coevolution, destroying adaptation to a given environment (which usually results in extinction) but permitting the population to adjust its niche and utilise a new environment.

Thus, in the present example of the A. scutellaris group, the association between habitat and abundance profiles may have resulted from the extinction of all populations with variant abundance profiles of the repetitive sequences. Therefore, the geographic distribution of these species appears to reflect a response, adaptation or adoptation, to genome evolution.

The selective importance of highly repeated sequences can be inferred from: (a) clinal variation in abundance (reviewed in John and Miklos, 1979), (b) correlation between the presence and amount of variable blocks of highly repetitive satellite DNA and the localisation and frequency of chiasmata (John and King, 1985), the higher frequencies being associated with less phenotypic variance (Miklos, 1982), (c) correlation between karyotype diversity and the diversity of highly repeated sequences (Gillespie et al., 1982) and (d) indirect regulation of developmental rates through (i) regulation of transport across the nuclear membrane (Cavalier-Smith, 1978 and 1982; but see Miklos, 1982) or (ii) hierarchical control of gene regulation (Bennet, 1982).

In the present study, PCA also clustered three species (representing both subgroups), including five populations of $A$. albopictus, all of which are restricted to islands dispersed throughout the Pacific. Here, the abundance of most sequences was relatively low. This may indicate that the colonisation of islands was followed by independent, rapid evolution of highly repeated sequences. Rapid genome evolution is also indicated by: (a) the 30 per cent greater genome size of island versus continental populations of $A$. albopictus and (b) the positive correlation between genome size and the amount of sequence variation within highly repeated DNA families (Flavell, 1982). Since the amount of variation within $A$. albopictus is large in comparison to that within the whole group, the genome of this species apparently evolves relatively rapidly. This in turn suggests a sequencedependent bias in the conversion events which homogenize populations for sequence variants of a repetitive DNA family.

Despite any selective significance inferred from PCA clustering, the highly repeated sequences do not appear to have any direct role in speciation. This is indicated by intraspecific variation which at least equals interspecific variation and which is not associated with postmating reproductive isolation between $A$. albopictus populations (McLain and Rai, 1986). Other studies have also failed to implicate the abundance of highly repeated sequences in reproductive isolation (Miklos, 1982; John and Miklos, 1979). However, this does not preclude an indirect role in either speciation or local adaptation, as discussed above. Of course, we cannot rule out that some key families may have greater importance. Also, sequence composition may be relatively more important than copy 
number, especially since concerted evolution (homogenisation of different variants) appears to be a between-species phenomenon (Dover, 1986).

Acknowledgements This research was supported in part by NIH grants 5T32 AI 07030 and 5R01 AI 21443 to K. S. Rai and USDA grant 84-CRCR-1-1386 to M. J. Fraser. Brian Turko assisted in the rearing and maintenance of mosquito stocks.

\section{REFERENCES}

BENNET, M. D. 1982. Nucleotypic basis of spatial ordering of chromosomes in eukaryotes and the implications of the order for genome evolution and phenotypic variation. In Dover, G. A. and Flavell, R. B. (eds.) Genome Evolution, Academic Press, NY, pp. 239-262.

BOUCHARD, R. A. 1982. Moderately repetitive DNA in evolution. International Review of Cytology, 76, 113-193.

BRANDSMA, J. AND MILleR, G. 1980. Nucleic acid spot hybridization: rapid quantitative screening of lymphoid cell lines for Epstein-bar viral DNA. Proceedings of the National Academy of Science (USA), 77, 6851-6855.

BRUTLAG, D. L. 1980. Molecular arrangement and evolution of heterochromatic DNA. Annual Review of Genetics, 14, 121-144.

CAVAliER-SMITH, T. 1978. Nuclear volume control by nucleoskeletal DNA: selection for cell volume and cell growth rate and the solution of the DNA c-value paradox. Journal of Cell Science, 34, 247-278.

CAVALIER-SMITH, T. 1982. Skeletal DNA and the evolution of genome size. Annual Review of Biophysics and Bioengineering, 11, 273-302.

COLliNS, S. AND GROUDINE, M. 1982. Amplification of endogenous myc-related DNA sequences in a human myeloid leukaemia cell line. Nature, 298, 687-691.

DOVER, G. 1981. The evolution of DNA sequences common to closely-related insect genomes. In Blackman, R. L., Hewitt, G. M. and Ashburner, M. (eds.) Insect Cytogenetics, Symposium of the Royal Entomological Society of London, 10, 13-35.

DOVER, G. 1982. Molecular drive: A cohesive mode of species evolution. Nature, 299, 111-117.

DOVER, G. 1986. Molecular drive in multigene families: how biological novelties arise, spread and are assimilated. Trends in Genetics, 2, 159-165.

DOVER, G., BROWN, S., COEN, E., DALlAS, J., STRACHAN, T. AND TRICK, M. 1982. The dynamics of genome evolution and species differentiation. In Dover, G. A. and Flavell, R. B. (eds.) Genome Evolution, Academic Press, NY, pp. 343-372.

DOWSETT, A. P. AND YOUNG, M. W. 1982. Differing levels of dispersed repetitive DNA among closely related species of Drosophila. Proceedings of the National Academy of Science (USA), 79, 4570-4574.

FLAVELL, R. B. 1982. Sequence amplification, deletion and rearrangement: major sources of variation during species divergence. In Dover, G. A. and Flavell, R. B. (eds.) Genome Evolution, Academic Press, NY, pp. 301-323.

FLEMING, J. G. W., BLISSARD, G. W., SUMMERS, M. D. AND VINSON, S. B. 1983. Expression of Campoletis sonorensis virus in the parasitoid host, Heliothis virescens. Journal of Virology, 48, 74-78.
FUCHS, E. AND GREEN, H. 1979. Multiple keratins of cultured human epidermal cells are translated from different mRNA molecules. Cell, 17, 573-582.

GILLESPIE, D., DONEHOWER, L. AND STRAYER, D. 1982. Evolution of primate DNA organization. In Dover, G. A. and Flavell, R. B. (eds.) Genome Evolution, Academic Press, NY, pp. 113-133.

hamadA, H. AND KAKUNAGA, T. 1982. Potential Z-DNA forming sequences are highly dispersed in the human genome. Nature, 298, 396-398.

JEFFREYS, A. J. 1982. Evolution of globin genes. In Dover, G. A. and Flavell, R. B. (eds.), Genome Evolution, Academic Press, NY, pp. 157-176.

JOHN, B. AND KING, M. 1985. The inter-relationship between heterochromatin distribution and chiasma distribution. Genetica, 66, 183-194.

JOHN, B. AND MIKLOS, G. L. G. 1979. Functional aspects of satellite DNA and heterochromatin. International Review of Cytology, 58, 1-114.

KAFATOS, F. C., JONES, C. W. AND EFSTRATIADIS, A. 1979 Determination of nucleic acid sequence homologies and relative concentrations by a dot hybridization procedure. Nucleic Acids Research, 7, 1541-1552.

LAW, M. L., DAVIDSON, J. N. AND KAO, F.-T. 1982. Isolation of a human repetitive sequence and its application to regional chromosome mapping. Proceedings of the National Academy of Science (USA), 79, 7390-7394.

MACGREGOR, H. C. 1982. Big chromosomes and speciation amongst Amphibia. In Dover, G. A. and Flavell, R. B. (eds.) Genome Evolution, Academic Press, NY, pp. 325341.

MANIATIS, T., FRITSCH, E. F. AND SAMBROOK, J. 1982. Molecular cloning: a laboratory manual, Cold Spring, Harbor Laboratory, 545 pp.

MARESCA, A., SINGER, M. F. AND LEE, T. N. H. 1984. Continuous reorganization leads to extensive polymorphism in a monkey centromeric satellite. Journal of Molecular Biology, 179, 629-649.

MCLAIN, D. K., RAI, K. S. AND FRASER, M. J. 1986. Interspecific variation in the abundance of highly repeated DNA sequences in the Aedes scutellaris (Diptera: Culicidae) subgroup. Annals of the Entomological Society of America, 79, 784-791

MCLAIN, D. K., RAI, K. S. AND RAO, P. N. 1985. Ethological divergence in allopatry and asymmetrical isolation in the south Pacific Aedes scutellaris subgroup. Evolution, 39, 998-1008

MCLAIN, D. K. AND RAI, K. S. 1986. Reinforcement for ethological isolation in the southeast Asian Aedes albopictus subgroup. Evolution, 40, 1346-1350.

MIKLOS, G. L. C. 1982. Sequencing and manipulating highly repeated DNA. In Dover, G. A. and Flavell, R. B. (eds.) Genome Evolution, Academic Press, NY, pp. 41-68.

NAGYLAKI, T. 1984. The evolution of multigene families under intrachromosome gene conversion. Genetics, 106, 529-548.

NAGYLAKI, T. AND PETES, T. D. 1982. Intrachromosomal gene conversion and the maintenance of sequence homogeneity among repeated genes. Genetics, 100, 315-337.

OHTA, T. 1985. A model of duplicative transposition and gene conversion for repetitive DNA families. Genetics, 110, 513524.

OHTA, T. AND DOVER, G. A. 1983. Population genetics of multigene families that are dispersed into two or more chromosomes. Proceedings of the National Academy of Science (USA), 80, 4079-4083.

OHTA, T. AND DOVER, G. A. 1984. The cohesive population genetics of molecular drive. Genetics, 108, 501-521. 
PAGES, M. J. M. AND ROIZES, G. P. 1984. Nature and organization of the sequence variations in the long-range periodicity of calf satellite DNA I. Journal of Molecular Biology, 173, 143-157.

PASHLEY, D. P. AND RAI, K. S. 1983. A comparison of allozyme and morphological relationships in some Aedes (Stegomyia) mosquitoes (Diptera: Culicidae). Annals of the Entomological Society of America, 76, 388-394.

PASHLEY, D. P., RAI, K. S. AND PASHLEY, D. N. 1985. A comparison of allozyme relationships with morphology, interspecific compatibility and geologic history in allopatric, island-dwelling mosquitoes. Evolution, 39, 985-997.

RAI, K. S., PASHLEY, D. P. AND MUNSTERMAN, L. E. 1982. Genetics of speciation in Aedine mosquitoes. In Steiner, W. M., Tabachnick, W. J., Rai, K. S. and Narang, S. (eds.) Recent Developments in the Genetics of Insect Disease Vectors, Stipes Publishing Company, Champaign, Illinois, pp. 84-129.

RAO, P. N. AND RAI, K. S. 1986. Chromosome evolution and phylogeny in some nematocerous families. Annals of the Entomological Society of America, in press.

SINGER, M. F. 1982. Highly repeated sequences in mammalian genomes. International Review of Cytology, 76, 67-112.

SKOWRONSKI, J., PLUCIENNICZAK, A., BEDNAREK, A. AND JAWORSKI, J. 1984. Bovine I-709 satellite: recombination hotspots and dispersed repeated sequences. Journal of Molecular Biology, 177, 399-416.

SMALL, D., NELKIN, B. AND VOGELSTEIN, B. 1982. Nonrandom distribution of repeated DNA sequences with respect to supercoiled loops and the nuclear matrix. Proceedings of the National Academy of Science (USA), 79, 5911-5915.

SMITH, G. E. AND SUMMERS, M. D. 1980. The bidirectional transfer of DNA and RNA to nitrocellulose or diazobenzyloxymethyl paper. Analytical Biochemistry, 109, 123-129.

SOUTHERN, E. 1975. Detection of specific sequences among DNA fragments separated by gel electrophoresis. Journal of Molecular Biology, 98, 503-517.

STRACHAN, T., COEN, E., WEBB, D. AND DOVER, G. A. 1982. Modes and rates of change of complex DNA families of Drosophila. Journal of Molecular Biology, 158, 37-54.

STRACHAN, T., WEBB, D. AND DOVER, G. A. 1985. Transition stages of molecular drive in multiple-copy DNA families in Drosophila. EMBO Journal, 4, 1701-1708.

STRAUS, N. A. 1971. Comparative DNA renaturation kinetics in amphibians. Proceedings of the National Academy of Science (USA), 68, 799-802.

VIEIRA, J. AND MESSING, J. 1982. The pUC plasmids, an M13mp7-derived system for insertion mutagenesis and sequencing with synthetic universal primers. Gene, 19, 259-268. 